\title{
PENDIDIKAN AKHLAK DALAM BERPAKAIAN BAGI PEREMPUAN MENURUT SURAT AN-NUR AYAT 31 DAN AL-AHZAB AYAT 59
}

(Kajian Tafsir Jalalain Karya Imam Jalaluddin Al-Mahalli dan Imam Jalaluddin As Suyuti)

\author{
Is Nurhayati
}

STIT Al-Khairiyah Cilegon

isnurhayati87@gmail.com

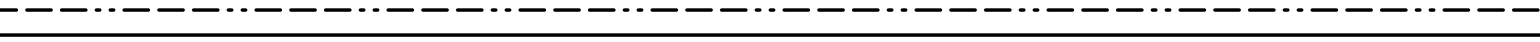

Abstrack

Islam teaches Muslim women to wear beautiful clothes for jewelry. The beauty and beauty of women come from two directions, namely physical beauty and inner beauty. Moral education serves as a guide for humans to be able to choose and determine an action, and then determine what is good and what is bad.

This study used qualitative research methods. Data collection techniques using library research by conducting a review of books, which have to do with the problem that will be solved both from primary data and secondary data. The primary data used are Al-Qur'an, and Tafsir Jalalain while for secondary data collection used are books and other written sources related to the core of the research.

The concept of moral education in the Qur'an is an effort made consciously to provide physical and spiritual education based on Islamic teachings in the form of the cultivation of noble morals which is a mirror of one's personality. Noble character will be able to deliver someone to high dignity. In the letter An-Nur verse 31 a Muslim woman must cover her nakedness, while the female nakedness is the whole body other than those that are excluded and not dressed tightly or dreamy so as to cause slander. And in the Surah Al-Ahzab verse 59 that there are some things that must be considered and applied to women, such as the suggestion to wear a veil that must cover the breasts and limbs,
\end{abstract}

Keywords: Moral, Dressed, Women

\begin{abstract}
Abstrak
Islam mengajarkan kepada kaum muslimah untuk memakai pakaian yang indah untuk perhiasan. Keindahan dan kecantikan perempuan bersumber dari dua arah, yaitu kecantikan ragawi dan inner beauty atau kecantikan dari dalam. Pendidikan akhlak berfungsi sebagai panduan bagi manusia agar mampu memilih dan menentukan suatu perbuatan, dan selanjutnya menetapkan mana yang baik dan mana yang buruk.

Penelitian ini menggunakan metode penelitian kualitatif. Tekhnik pengumpulan data menggunakan library research dengan mengadakan penelaah terhadap buku-buku, yang ada hubungannya dengan masalah yang akan di pecahkan baik dari data primer maupun data sekunder. Adapun data primer yang digunakan adalah Al-Qur'an, dan Tafsir Jalalain sedangkan untuk pengumpulan data sekunder yang digunakan adalah buku-buku dan sumber tertulis lainnya yang berhubungan dengan inti penilitian.
\end{abstract}


Konsep pendidikan akhlak dalam Al-Qur'an merupakan suatu usaha yang dilakukan secara sadar guna memberikan pendidikan jasmani dan rohani berdasarkan ajaran Islam yang berupa penanaman akhlak mulia yang merupakan cermin kepribadian seseorang. Akhlak yang mulia akan mampu mengantarkan seseorang kepada martabat yang tinggi. Dalam surat An-Nur ayat 31 seorang perempuan muslimah harus menutup auratnya, sedangkan aurat perempuan adalah seluruh tubuh selain yang dikecualikan dan tidak berpakaian ketat atau yang menerawang sehingga memunculkan fitnah. Dan dalam surat Al-Ahzab ayat 59 yaitu Ada beberapa hal yang mesti diperhatikan dan diterapkan pada diri perempuan, seperti anjuran memakai jilbab yang harus menutupi dada dan anggota tubuhnya,

Kata Kunci: Akhlah, Berpakaian, Perempuan 


\section{A. PENDAHULUAN}

Islam mengajarkan kepada pemeluknya agar berakhlak yang baik. Akhlak yang terpuji bagi seorang muslim mempunyai kedudukan yang sangat penting bahkan salah satu risalah yang diemban Nabi Muhammd SAW adalah menyempurnakan akhlak. Ini semua karena beliau seorang yang diakui kebaikan akhlaknya baik oleh manusia maupun Allah.

Islam mengajarkan kepada kaum muslimah untuk memakai pakaian yang indah untuk perhiasan karena unsur mutlak keindahan adalah kebersihan. Itulah sebabnya kenapa Nabi Muhammad SAW, Senang memakai pakaian putih, bukan saja karena warna ini lebih sesuai dengan iklim jazirah arab yang panas, melainkan juga karena putih segera menampakkan kotoran, sehingga pemakainya akan segera terdorong untuk mengenakan pakaian lain yang bersih. Keindahan dan kecantikan perempuan bersumber dari dua arah, yaitu kecantikan ragawi dan inner beauty atau kecantikan dari dalam. Kecantikan dari luar bisa terlihat dari wajah, cara berpakaian dan badannya. Sedangkan kecantikan yang tidak dapat menipu adalah kecantikan inner beauty bisa terlihat dari bagaimana ia bersikap, berbicara dan juga berkata-kata yang sopan dan lembut.

Berbicara mengenai kecantikan ragawi, Islam mewajibkan kaum hawa untuk menutup auratnya. Perbincangan masalah aurat memang tak pernah lekang dan memang tidak boleh disepelekan. Karena aurat merupakan sesuatu yang paling berharga dan terhormat dalam tubuh kita sehingga tidak menimbulkan kemurkaan. Akhlak yang mulia merupakan barometer terhadap kebahagiaan, keamanan dan ketertiban dalam masyarakat. Dapat dikatakan bahwa akhlak ini merupakan tiang berdirinya suatu bangsa. Dengan kata lain, apabila rusak akhlak suatu bangsa maka rusak pula bangsa itu. Begitu pentingnya akhlak bagi manusia, banyak ayat Al-Qur'an dan hadits yang membicarakan tentang akhlak. Termasuk dari kesempurnaan iman seseorang bisa dilihat dari akhlaknya. Sebagaimana firman Allah SWT, di dalam Al-Qur'an yang berbunyi:



Artinya: "Dan sesungguhnya kamu benar-benar berbudi pekerti yang agung" (Q.S. AlQalam [68]: 4). ${ }^{1}$

Kemerosotan akhlak sekarang ini, bukan hal yang aneh bila berita-berita dalam media massa seperti koran, majalah, hampir tiap hari memuat kejadian-kejadian yang mengancam keterpurukan nilai-nilai budaya baik yang terjadi didalam negeri ataupun diluar negeri. Misalnya: perampokan, penodongan, pembunuhan, pemerkosaan, narkoba dan korupsi yang semakin merajalela dilingkungan kita, tanpa memperhitungkan nilainilai moral Islam, yang pada akhirnya akhlak kita semakin terancam serius.

Saat ini, pakaian sudah memliki arti ganda, yaitu selain sebagai alat penutup aurat pakaian berkembang menjadi trend dan mode. Banyak sekali model pakaian yang keluar dipasaran. Karena perkembangannya, pakaian yang diproduksi tidak semuanya pantas digunakan dan menutup aurat. Semakin banyak model pakaian yang justru mempertontonkan aurat manusia, dan pasaran yang banyak dibikin untuk model pakaian

1 Depag RI, Op.Cit, hal. 451 
seperti ini adalah perempuan. Untuk itu, kaum hawa harus benar-benar teliti dalam berbusana dan memilih pakaian.

Banyak sekali kejahatan kejahatan syahwat yang terjadi akibat perempuan yang salah memilih pakaian yang tidak benar-benar menutup aurat mereka. Dan salah satu aurat yang wajib di tutupi oleh perempuan adalah rambut, yaitu dengan menggunakan jilbab. Jilbab adalah salah satu identitas seorang muslimah, jilbab bisa menjaga seorang perempuan dari hal-hal yang membahayakan, karena salah satu fungsi jilbab adalah menutup aurat kita. Sebagaimana firman Allah SWT dalam Al-Qur'an surat Al-Ahzab ayat 59

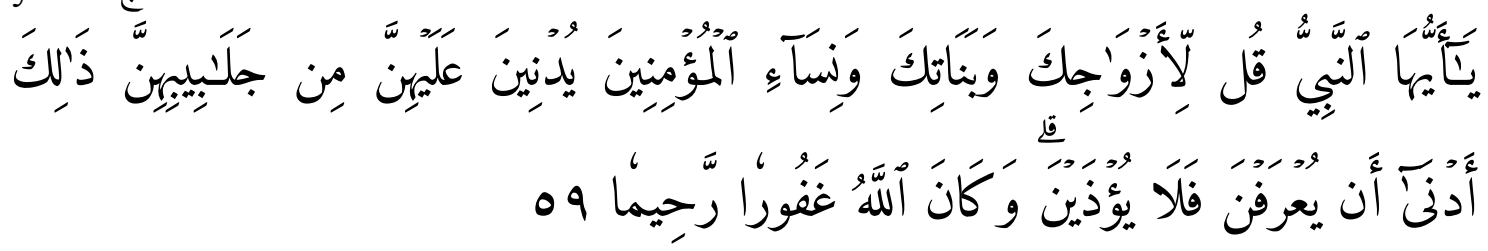

Artinya: "Hai Nabi, katakanlah kepada isteri-isterimu, anak-anak perempuanmu dan isteri-isteri orang mukmin: "Hendaklah mereka mengulurkan jilbabnya ke seluruh tubuh mereka". Yang demikian itu supaya mereka lebih mudah untuk dikenal, karena itu mereka tidak di ganggu. Dan Allah adalah Maha Pengampun lagi Maha Penyayang" (Q.S. Al-Ahzab [33]: 59) ${ }^{2}$

Menurut buku Tafsir Jalalain, ayat diatas menjelaskan tentang anjuran untuk kaum perempuan muslim hendaklah mereka mengulurkan jilbabnya untuk menutupi seluruh tubuhnya. Karena aurat perempuan adalah seluruh tubuh. Hal ini juga untuk menjaga dari gangguan orang-orang munafik, dan membedakan antara perempuan merdeka dan hamba sahaya perempuan. ${ }^{3}$

Dari kemerosotan dan keterpurukan akhlak yang semakin terancam serius, perlu adanya filterisasi yang didasarkan kepada Al-Qurán dan Hadits. Kita sebagai orang Islam sangat penting sekali untuk mempelajari dan memahami Al-Qurán dan Hadits sebagai sumber akhlak kita. Agar akhlak kita semakin sempurna, sehingga dengan kesempurnaan itulah disebut dengan akhlaqul karimah yang betul-betul Islami.

Untuk mengaplikasikan kesempurnaan akhlak dalam kehidupan sehari-hari, baik hubungannya itu dengan vertikal (kholiq) ataupun dengan horizontal (sesama mahkluk) perlu adanya metode pendidikan yang mendasar, yaitu melalui pendidikan akhlak dengan cara formal ataupun melalui pendidikan akhlaq dengan cara non formal. Melalui pendidikan akhlak inilah kita dapat mencetak dan membentuk watak dan kepribadian manusia, sehingga setelah semuanya itu berbentuk baik, maka baik pulalah akhlaknya. Serta dapat di aplikasikan dalam kehidupan sehari-hari. Perilaku kita mendapat kedudukan yang lebih tinggi dan terhormat, baik dihadapan Allah SWT ataupun dihadapan sesama manusia, sehingga kedudukan akhlak dalam kehidupan manusia menempati tempat yang penting secara individu maupun sebagai anggota masyarakat.

2 Depag RI, Op.Cit, hal. 350

3 Imam Jalaluddin Al-Mahalli, Imam Jalaluddin As-Suyuti, Tafsir Jalalain, Op-Cit, hal. 533 
Mengingat pentingnya pendidikan akhlak bagi terciptanya kondisi lingkungan yang harmonis, diperlukan upaya serius untuk menanamkan nilai-nilai tersebut secara insentif. Pendidikan akhlak berfungsi sebagai panduan bagi manusia agar mampu memilih dan menentukan suatu perbuatan, dan selanjutnya menetapkan mana yang baik dan mana yang buruk.

Penulis melihat, bahwa Al-Qur'an Surat An-Nisa ayat 31 dan Surat Al-Ahzab ayat 59 memiliki kandungan tentang akhlak yang sangat dalam. Di antara kandungan yang terdapat didalamnya adalah ajaran bahwa umat manusia menjunjung penghormatan kaum muslimah dalam adab berpakain dengan baik, karena menutup aurat adalah salah satu akhlak yang mulia.

Dari latar belakang masalah yang telah dikemukakan diatas, maka penulis merumuskan beberapa masalah sebagai berikut:

1. Bagaimana konsep pendidikan akhlak dalam Al-Qur'an?

2. Bagaimana cara berpakaian bagi perempuan menurut Surat An-Nur Ayat 31 dan Surat Al-Ahzab Ayat 59 dalam kajian Tafsir Jalalain?

\section{B. METODE}

Penelitian ini, penulis menggunakan metode penelitian kualitatif. Tekhnik pengumpulan data menggunakan library research yaitu dengan mengadakan penelaah terhadap buku-buku yang ada hubungannya dengan masalah yang akan di pecahkan baik dari data primer maupun data sekunder. Adapun data primer yang digunakan adalah AlQur'an, dan Tafsir Jalalain sedangkan untuk pengumpulan data sekunder yang digunakan adalah buku-buku dan sumber tertulis lainnya yang berhubungan dengan inti penilitian. Metode penelusuran dan penelaahan secara mendalam terhadap literatur primer dan sekunder diharapkan bisa mendapatkan sebuah data yang akurat dan jelas.

Analisis data merupakan mencari dan menyusun data yang diperoleh dari dokumentasi melalui mengklasifikasikan hal-hal yang penting dan yang akan dipelajari dan membuat kesimpulan. Sesudah data-data terkumpul, kemudian dianalisa secara keseluruhan untuk diambil kesimpulan yang bersifat khusus dan relevan. ${ }^{4}$ Untuk mencapai maksud tersebut di perlukan beberapa metode sebagai berikut :

a. Deskriptif

Deskriptif adalah menguraikan secara teratur penafsiran Jalalain, tentang ayat yang telah di himpun sesuai dengan tema dan persoalan yang telah di rumuskan.

b. Holistika

Metode ini menyajikan pemikiran Jalalain secara komperensif. Maksudnya, penulis akan menggali unsur-unsur pemikiran tokoh tersebut, sebab untuk memahami manusia, seorang penulis harus memahami seluruh kenyataannya, sehingga peneliti bisa lebih arif dan bijaksana dalam meneropong sebuah pemikiran.

c. Interpretasi 
Interpretasi berarti menafsirkan pemikiran secara objektif. Metode ini digunakan untuk memahami dan menyelami data yang terkumpul untuk kemudian mengungkap arti dan nuansa yang di maksud tokoh secara khas.

C. HASIL DAN PEMBAHASAN

Penafsiran Surat An-Nur Ayat 31

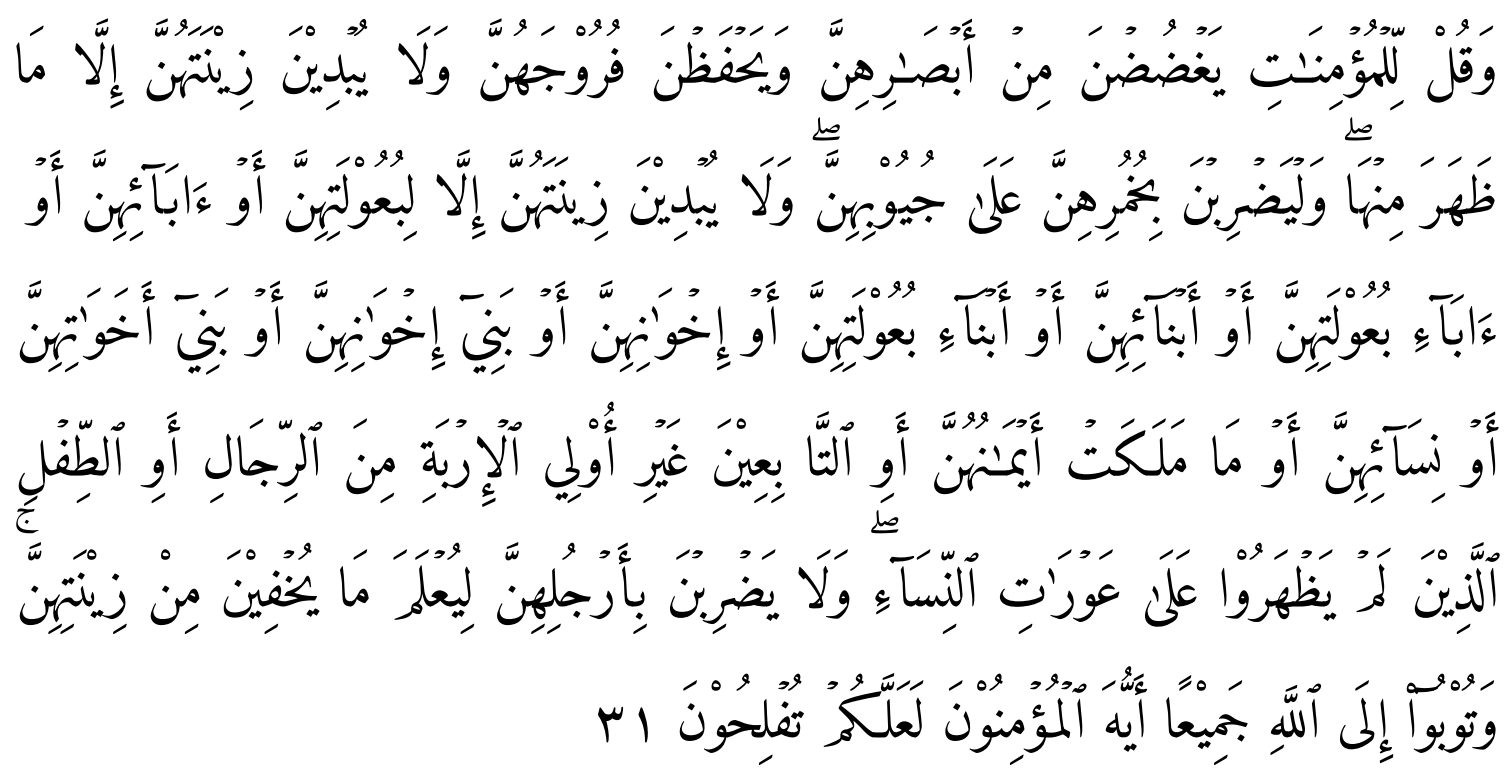

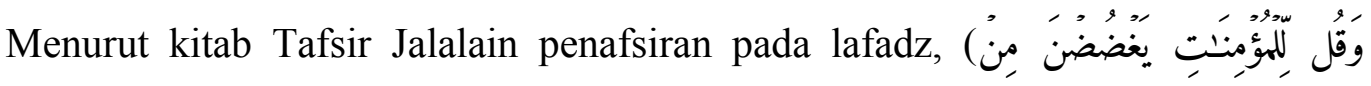
"Dan katakanlah kepada wanita yang beriman: "Hendaklah mereka menahan pandangannya" dari hal-hal yang tidak di halalkan bagi mereka melihatnya. Maksudnya seorang perempuan harus menjaga pandangannya kepada laki-laki lain yang bukan muhrimnya, baik dengan pandangan hawa nafsu ataupun dengan pandangan yang biasa, karena akan menimbulkan fitnah.

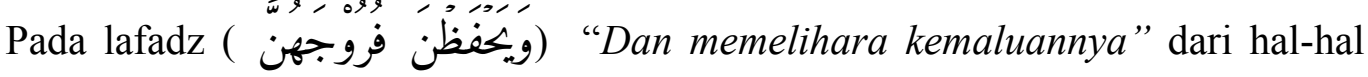
yang tidak dihalalkan untuknya. Maksud memelihara kemaluan disini adalah, seorang perempuan harus menjaga kehormatannya dari perbuatan keji seperti zina, lesbian, homoseksual dan berbagai bentuk tindakan amoral lainnya, yang merugikan diri sendiri.

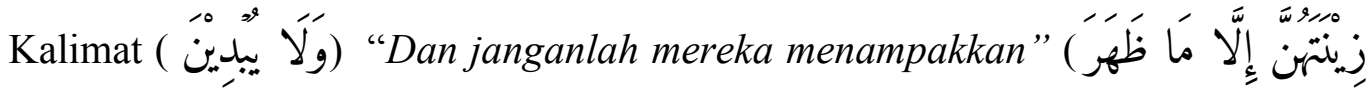

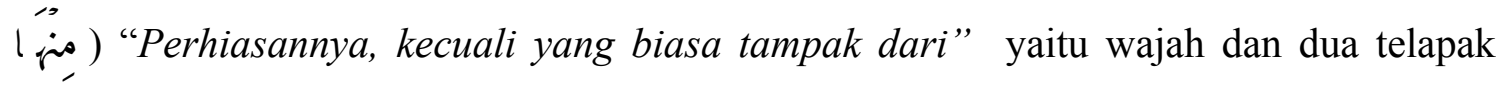
tangannya, maka kedua perhiasannya itu boleh dilihat oleh lelaki lain, jika tidak dikhawatirkan adanya fitnah. Demikianlah menurut pendapat yang membolehkannya. Akan tetapi menurut pendapat yang lain hal itu diharamkan secara mutlak, sebab 
merupakan sumber terjadinya fitnah. Pendapat yang kedua ini lebih kuat demi untuk menutup pintu fitnah. Akan tetapi secara umum kandungan ayat ini mencakup pakaian biasa jika dihiasi dengan sesuatu yang menyebabkan kaum laki-laki melirikkan pandangan kepadanya.

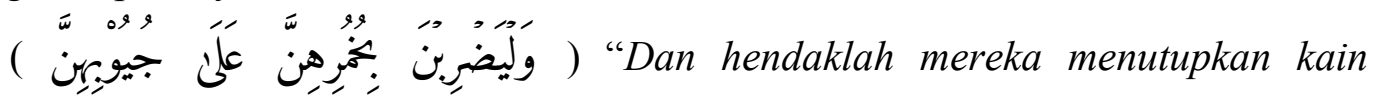
kerudung kedadanya" hendaklah mereka menutupi kepala, leher, dan dada mereka

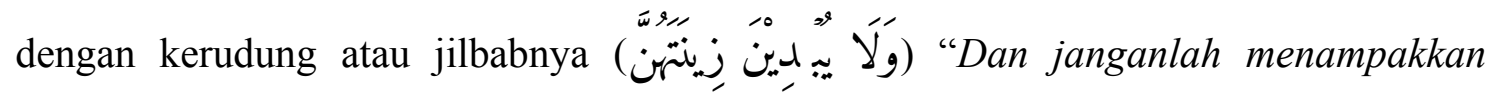
perhiasannya" perhiasan yang tersembunyi, yaitu selain dari wajah dan kedua telapak

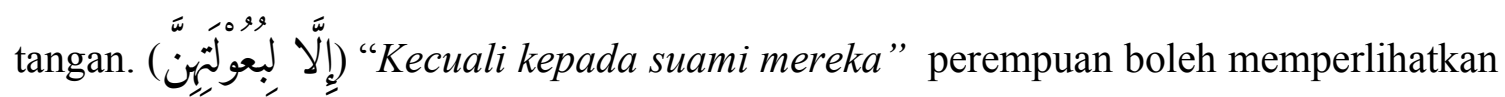

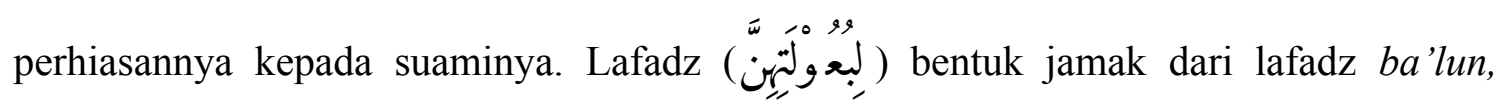
artinya suami.



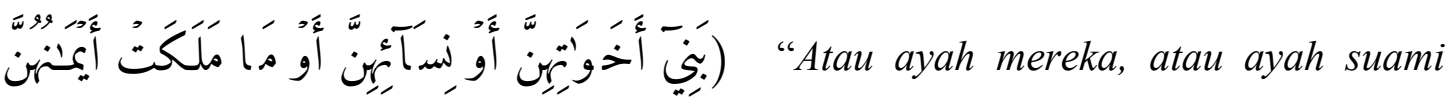
mereka, atau putera-putera mereka, atau putera-putera suami mereka, atau saudarasaudara laki-laki mereka, atau putera-putera saudara lelaki mereka, atau putera-putera saudara perempuan mereka, atau wanita-wanita islam, atau budak-budak yang mereka miliki" diperbolehkan bagi mereka melihatnya kecuali anggota tubuh antara pusar dan lututnya, anggota tersebut haram untuk dilihat oleh mereka selain dari suaminya sendiri. Dikecualikan dari lafadz nisa-ihinna, yaitu perempuan-perempuan yang kafir, bagi perempuan muslimah tidak boleh membuka aurat di hadapan mereka. Termasuk pula kedalam pengertian mamalakat aimanuhunna, yaitu hamba sahaya laki-laki miliknya.

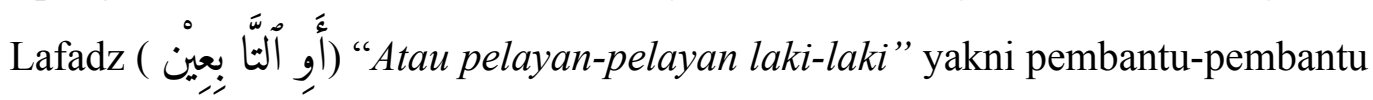
laki-laki ( غَرِ ) "Yang tidak” kalau dibaca gairi berarti menjadi sifat, dan kalau di baca

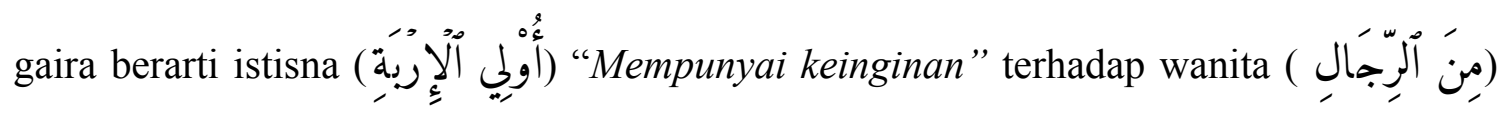
"Dari kalangan kaum laki-laki” seumpanya penis masing-masing tidak dapat bereaksi (

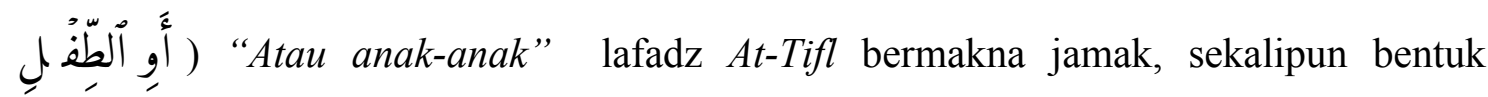

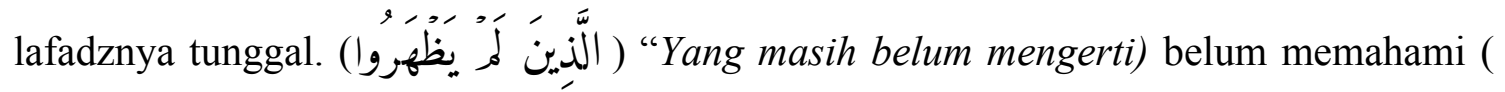
"Tentang aurat wanita” belum mengerti persetubuhan, maka kaum perempuan boleh menampakkan aurat mereka terhadap orang-orang tersebut selain

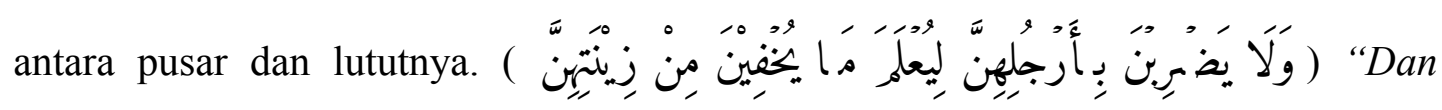


janganlah mereka memukulkan kaki mereka agar diketahui perhiasan yang mereka sembunyikan" yaitu berupa gelang kaki, sehingga menimbulkan suara gemerincing.

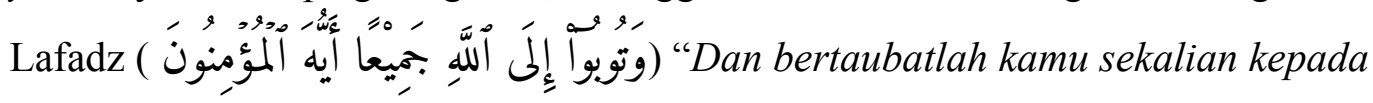

Allah, hai orang-orang yang beriman" dari apa yang telah kalian kerjakan, yaitu sehubungan dengan pandangan yang dilarang ini dan hal-hal lainnya yang dilarang (


taubat kalian diterima. Pada ayat ini ungkapan muzakkar mendominasi atas muannas. ${ }^{5}$

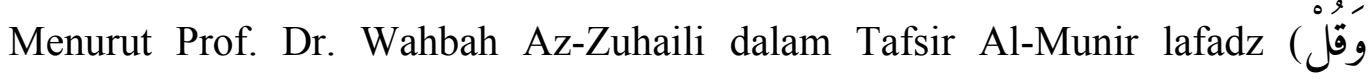
Wahai Rasul, katakanlah kepada para kaum perempuan mukminah, tahanlah penglihatan kalian terhadap apa yang diharamkan oleh Allah SWT. Janganlah kalian memandang melainkan kepada suami-suami kalian. Selain itu jagalah kemaluan kalian dari perbuatan zina dan lain sebagainya, seperti assihaaq (Lesbian). Oleh karena itu seorang perempuan tidak boleh memandang kepada laki-laki asing, baik dengan syahwat maupun tidak. Akan tetapi ada beberapa ulama lain yang memperbolehkan perempuan melihat laki-laki asing tanpa syahwat selain antara pusar dan lutut. Kemudian Allah SWT menuturkan sejumlah hukum yang khusus untuk kaum perempuan.


perhiasan yang mereka kenakan kepada laki-laki asing. Perhiasan disini bersiafat umum mencakup segenap perhiasan yang digunakan untuk menghias dan mempercantuk diri. Janganlah mereka mereka menampakkan bagian-bagian tubuh yang menjadi tempat perhiasan. Dalam potongan ayat ini terdapat majaz dalam bentuk menyebutkan perhiasan, tetapi yang di maksud ayat ini adalah bagian-bagian tubuh yang menjadi tempat perhiasan. Tujuan utamanya adalah larangan menampakkan bagian-bagia tubuh yang menjadi tempat perhiasan seperti dada, telinga, leher, lengan bawah, lengan atas

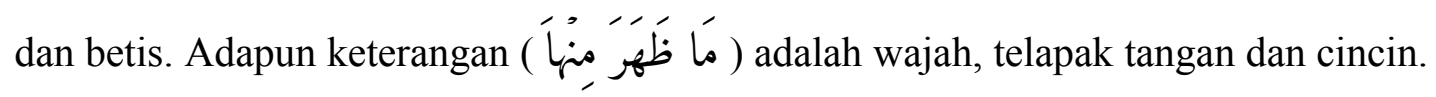

Berdasarkan ini ulama Hanafiyyah, ulama Malikiyyah, dan Imam Asy-Syafi'i dalam sebuah versi qaulnya mengatakan, bahwa wajah dan kedua telapak tangan bukanlah aurat. Oleh karena itu, yang di maksud (مَا ظَهَرَ مُنْاً ) ialah yang biasa nampak. Sedangkan Imam Ahmad dan Imam Asy-Syafi'i dalam salah satu dua qaul-nya, yang lebih shahih mengatakan bahwa seluruh tubuh peremuan adalah aurat. Hal ini berdasarkan hadits tentang pandangan tiba-tiba yang tidak disengaja didalamnya, dan diperintahkan untuk menundukkan dan mengalihkan pandanagnnya.

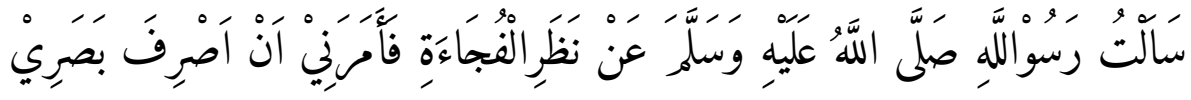

5 Jalaluddin Al-Mahali, Jalaluddin -Suyuti, Tafsir Jalalain, Op-Cit, hal. 238-240 
Artinya: "Aku bertanya kepada rasulullah saw, tentang pandanagan tiba-tiba, lalu beliau memerintahkanku supaya aku mengalihkan penglihatanku.” (HR. Muslim, Ahmad, Abu Dawud, At-Tirmidzi, dan An-Nasa'i)

Apabila melihat sesuatu yang diharamkan dengan ketidak sengajaan maka segeralah menundukan kepala dan mengalihkannya ke hal-hal lain yang tidak diharamkan untuk dilihat. Hal ini berdasarkan hadis yang di riwayatkan oleh Imam Muslim dalam shahihnya, Ahmad, Abu Dawud, At-Tirmidzi dan An-Nasa'i dari Jarir Bin Abdillah Al-Bajali R.A.

Sebab dibalik perintah menahan pandangan adalah untuk menutup celah-celah yang bisa menjadi pintu masuk terjadinya kerusakan dan hal-hal yang negatif, mencegah terjadinya perbuatan dosa dan kemaksiatan. Sesungguhnya pandangan adalah kurir untuk bisa masuk pintu perzinaan, karena lewat pandangan akan mempengaruhi hati.

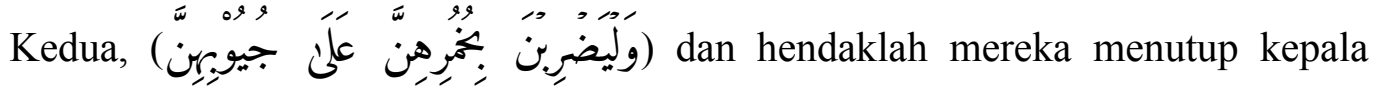
mereka sampai pada bagian-bagian dada untuk menutupi rambut kepala, leher dan dada. Hal ini adalah perintah tuntunan untuk menutupi bagian-bagian tubuh yang menjadi tempat perhiasan yang tesembunyi bagi kaum perempuan. Bukhari meriwayatkan dari Aisyah R.A ia berkata;

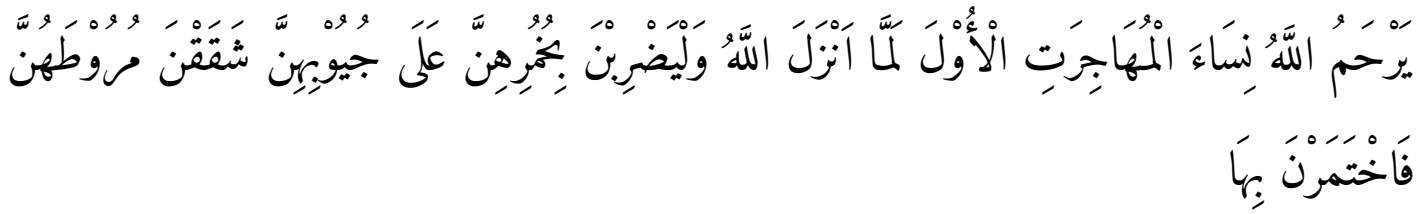

Artinya; "Semoga Allah melimpahkan rahmat-Nya kepada kaum perempuan muhajirin generasi pertama, ketika Allah STW menurunkan ayat 'wal yadhribna bi khumurihinna ala juyubihinna', maka mereka langsung menyobek muruuth (kain lebar yang di gunakan untuk menyelimuti seluruh tubuh, jubah), mereka yang menggunakan sebagiannya untuk kerudung”. (HR. Bukhari)

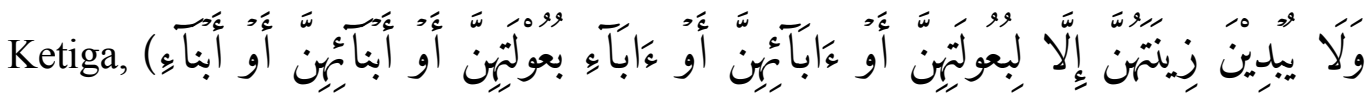

dan janganlah mereka menampakkan

perhiasan mereka yang tersembunyi, kecuali kepada suami-suami mereka, karena para istri tidak lain untuk para suami mereka. Selain kepada suami yaitu kepada bapak, kakek, ayah mertua, anak, saudara laki-laki dan yang tergolong dalam mahramnya. Maka seorang perempuan boleh menampakkan perhiasannya kepada mereka, tetapi dengan syarat tidak mengandung sikap tabarruj.

Akan tetapi ayat ini tidak menyebutkan kerabat nasab berupa paman dari jalur ayah (saudara laki-laki ayah) dan paman dari jalur ibu (saudara laki-laki ibu). Karena posisi paman adalah seperti posisi orang tua, dan ayat ini pun tidak menyebutkan kerabat mahram dari jalur persusuan. Akan tetapi ada nash dari as-sunah yang menjelaskannya, yaitu seperti hadis yang diriwayatkan oleh Ahmad, Bukhari, Muslim, Abu Daud, AnNasa'i dan Ibnu Majah dari Aisyah R.A 


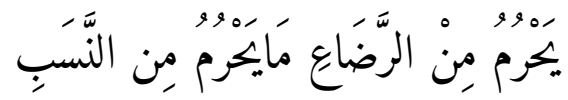

Artinya: " Jalur jalur kerabatan mahram dari nasab juga berlaku pada jalur persusuan." (HR. Ahmad, Bukhari, Muslim, Abu Daud, An-Nasa'i dan Ibnu Majah).

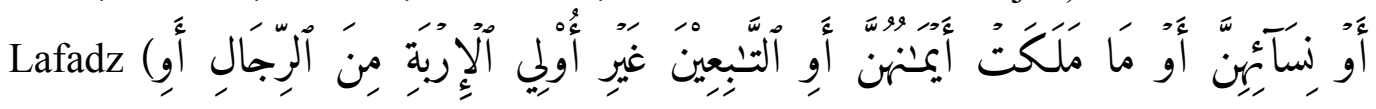

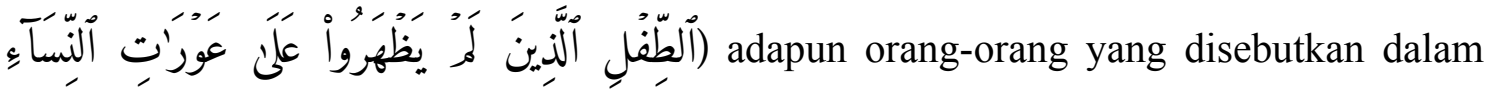
lanjutan ayat ini adalah orang-orang yang boleh bagi seorang perempuan untuk menampakkan perhiasan yang tersembunyi dihadapan mereka, selain diantara pusar dan lutut. Karena mereka itu sesama perempuan, budak milik, orang-orang yang ikut hidup yang tidak memiliki kebutuhan dan birahi kepada perempuan seperti orang terkebiri dan orang idiot. Selain itu juga boleh menampakkan kepada anak-anak yang belum paham tentang masalah perempuan dan aurat perempuan sertabelum memahami tentang persoalan seks.

Akan tetapi terdapat perbedaan pendapat diantara para ulama menyangkut sesama kaum perempuan tersebut. Jumhur Ulama mengatakan bahwa yang dimaksud bukanlah semua kaum perempuan, akan tetapi yang dimaksud adalah sesama kaum perempuan muslimah saja, tanpa mencakup perempuan kafir dzimmi. Dan seoarang perempuan muslimah tidak diperbolehkan untuk menceritakan bahwa ia telah melihat tubuh sesama perempuan muslimah kepada suaminya atau laki-laki lain.

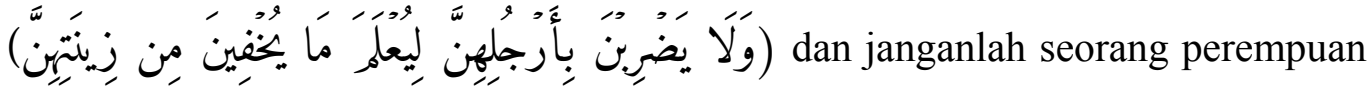
menghendak-hendakkan kakinya ketika berjalan, agar terdengar suara keronconcong yang dipakenya. Sebab itu adalah tindakan yang sangat berpotensi memicu timbulnya fitnah dan kerusakan, menarik perhatian, merangsang birahi dan syahwat, serta munculnya pikiran negatif terhadapnya sebagai perempuan nakal.

dan kembalilah kalian kepada

ketaatan Allah SWT, dan bertaubatlah kalian kepada-Nya wahai orang-orang mukmin semuanya. Laksanakanlah apa yang dia perintahkan kepada kalian berupa sifat-sifat dan akhlak terpuji seperti menahan pandangan dan menjaga kemaluannya. Dan tinggalkanlah apa-apa yang dilarang, seperti masuk rumah oramg lain tanpa permisi. Bertaubatlah dan beristighfarlah memohon ampunan dari berbagai kesalahan kekeliruan dan kekhilafan. Sesungguhnya taubat adalah sebab musabab keberuntungan dan keberhasilan menggapai kebahagiaan dunia akhirat. ${ }^{6}$

Menurut buku Tafsir Ibnu Kasir yang dikarang oleh Al-Imam Abul Fida Isma'il Ibnu Kasir Ad-Dimasyqi, dalam ayat di atas menjelaskan bahwa perempuan di haramkan memandang laki-laki lain selain suaminya, baik dengan padanga birahi ataupun tidak. Dan menjaga kemaluannya dari perbuatan keji, dan larangan untuk menampakkan sesuatu dari perhiasannya kepada laki-laki lain, kecuali apa yang tidak

6 Wahbah Az-Zuhaili, Tafsir Al-Munir : Aqidah, Syari'ah, Manhaj, jilid 9(Depok: Gema Insani, 2016), hal. 498-505 
bisa di sembunyikan. Menurut Ibnu Mas'ud hal yang di maksud adalah seperti kain selendang dan pakaiannya, yakni seperti pakaian tradisi kaum arab yang menutupi seluruh tubuhnya. Sedangkan bagian bawah pakaian yang kelihatan tidaklah berdosa, sebab bagian ini tidak bisa di sembunyikan. Hal ini sama berlaku pula pada pakaian perempuan lainnya yang bagian bawah kainnya kelihatan karena tidak dapat ditutupi.

"Dan hendaklah mereka menutupi kain kerudung kedadanya" yakni kain kerudung yang panjang agar dapat menutupi dada dan bagian sekitarnya, agar berbeda dengan perempuan jahiliyah. Karena perempuan jahiliyah cara berpakaiannya tidak seperti ini, bahkan ketika mereka lewat dihadapan laki-laki mereka membusungkan dadanya tanpa di tutupi kin sehelaipun.

Al-khumur adalah bentuk jamak dari khimar yang artinya kain kerudung yang dipakai untuk menutupi kepala, dikenal pula dengan sebutan muqani. Said ibnu Jubair telah mengatakan sehubungan dengan makna firman-Nya; "Dan hendaklah mereka menutupi kain kerudung kedadanya" (QS. An-Nur:31) maksunya, menutupi bagian leher dan dadanya maka tidak boleh ada sesuatu pun dari bagian tersebut yang tampak.

Perempuan boleh memperlihatkan perhiasannya kepada mahramnya, dengan syarat tidak dengan cara tabarrujj (memamerkan diri atau mengundang perhatian lawan jenis). Begitupun seorang perempuan boleh menampakkan perhiasannya kepada perempuan muslimah, bukan dengan perempuan kafir zimmi. Agar mereka tidak menceritakan keadaan kaum perempuan muslimah kepada kaum laki-laki mereka. Hukum larangan ini berlaku kesemua perempuan, hanya saja lebih berat larangannya kepada perempuan kafir zimmi. Dan perempuan pun boleh menampakkan perhiasannya kepada laki-laki yang tidak mempunyai keinginan terhadap perempuan selain itu akal mereka kurang dan lemah. Atau boleh kepada anak-anak yang belum baligh dan belum mengerti dengan keadaan perempuan dan aurat.

Dan janganlah seorang perempuan berjalan dengan memukul-mukulkan kakinya ke tanah sehingga kaum laki-laki pun mendengar suara keroncongan gelangnya, dengan bermaksud menarik perhatian mereka. Hal ini dilarang oleh Allah SWT. Begitupun dengan memakai parfum bila keluar rumah, sebab kaum laki-laki pun akan mencium baunya.

Abu Isa At-Tirmizi mengatakan, telah menceritakan kepada kami Muhammad Ibnu Basysyar, telah menceritakan kepada kami Yahya Ibnu Sa'id Al-Qattan, dari Sabit Ibnu Imarah Al-Hanafi, dari Gamin Ibnu Qais, dari Abu Musa R.A dari Nabi Muhammad SAW, yang telah bersabda:

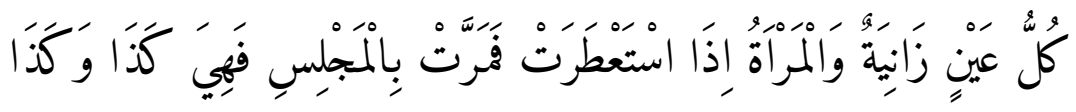

Artinya; "Setiap mata ada zinanya. Seseorang perempuan bila memakai wewangian, lalu melewati suatu majelis, maka dia akan memperoleh dosa anu dana nu. (HR. Imam Abu Daud Dan Imam Nasa'i)

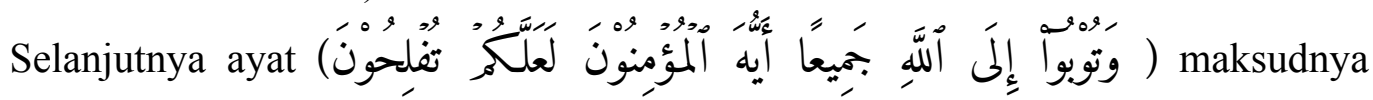
adalah kerjakanlah segala sesuatu yang telah aku perintahkan kepada kalian, yaitu dengan menghiasi diri dengan sifat-sifat yang terpuji dan akhlak yang mulia. Dan 
tinggalkanlah tradisi masa lalu di zaman jahiliyah, dengan cara meninggalkan sifat dan akhlaknya yang rendah. Karena sesungguhnya keberuntungan yang paling utama berada dalam jalan mengerjakan segala sesuatu yang di perintahkan oleh Allah dan Rasul-Nya dan meninggalkan segala sesuatu yang dilarang oleh keduanya. Hanya kepada Allah sajalah kita memohon ampun pertolongan. ${ }^{7}$

Menurut Murtadha Muthahhari dalam buku Teologi dan Falsafah Hijab, dalam ayat "Janganlah mereka menampakkan perhiasan mereka," terdapat dua perkecualian didalam Al-Qur'an. Pertama " Kecuali yang biasa ditampakkan," seperti celak, cincin dan gelang . dan yang kedua adalah " Kecuali kepada suami-suami mereka”. Perhiasan yang dipakai pada dua tangan dan wajah tidaklah wajib bagi perempuan untuk menutup wajah atau tangan mereka. Benda-benda yang menghiasi mereka boleh tampak selama benda-benda tersebut lazim digunakan orang. Karena perhiasan yang dipakai di tangan dan wajah tidak wajib untuk di tutup.

Menurut Imam Shadiq perhiasan yang boleh ditampakkan yaitu, perhiasan yang berupa celak, dan cincin dan keduanya ada di wajah dan tangan. Begitupun Abi Basir sa'at dia bertanya kepada Imam Shadiq tentang perkecualian dalam hal ini, beliau menjawab cincin dan gelang. Bahwa perkecualian tersebut adalah wajah dan tangan. Jika wajah dan tangan tidak perlu ditutup, demikian pula dengan perhiasan yang ada dibagian tubuh itu.

Dalam hadits yang di riwayatkan Ali Bin Ibrahim dari Imam Baqir beliau ditanya tentang perkecualian ini dan beliau menjawab yaitu pakaian perempuan, celak, cincin,pewarna pada telapak tangan, dan gelang. Kemudian Imam Baqir menjelaskan tentang tiga tingkatan perhiasan, yaitu perhiasan yang semua orang bisa melihat, perhiasan yang boleh dilihat oleh muhrim, dan perhiasan bagi pasangan suami istri. Perhiasan yang boleh ditampakkan kepada orang lain adalah wajah dan tangan, dan gelang, perhiasan yang boleh di lihat oleh muhrimnya yaitu leher, kalung, gelang tangan, gelang kaki. Namun untuk suami, seorang perempuan boleh memperlihatkan seluruh tubuhnya, hal ini yang dimaksud dengan perhiasan bagi pasangan suami istri. ${ }^{8}$

Dalam ayat di atas ditegaskan kewajiban untuk menutup seluruh perhiasan, tidak melihatkan sedikitpun diantaranya, kepada laki-laki yang bukan muhrimnya, kecuali perhiasan yang tampak tanpa kesengajaan dari mereka (kaum perempuan) maka mereka tidak dihukum tanpa kesengajaan itu jika mereka tidak segera menutupnya. Al-Hafidz Ibnu Kasir berkata dalam tafsirnya, "Maksudnya, jangan lah kaum perempuan menampakkan sedikitpun dari perhiasan mereka kepada laki-laki yang bukan muhrimnya, kecuali yang tidak mungkin di sembunyikan". 9

Yang dimaksud dengan perintah mengenakan jilbab adalah menutupi perhiasan wanita. Dengan demikian tidak masuk akal jika jilbab itu berfungsi sebagai perhiasan. Oleh karena itu Al-Imam Al-Kabair mengatakan, "Diantaranya perbuatan yang

7 Al-Imam Abul Fida Isma'il, Ibnu Kasir Ad-Dimasyqi, Tafsir Ibnu Kasir Juz 18,(Bandung: Sinar Baru Algensindo,2007), Hal. 273-290

8 Murtadha Muthahhari, Teologi dan Falsafah Hijab, (Yogyakarta: Rausyanfikr Institute, 2015), hal. $86-88$ Cit, hal. 49

9 Syaikh Muhammad Nashirudin Al-Bani, Jilbab Wanita Muslimah Menurut Qur'an dan Sunah, Op- 
menyebabkan perempuan itu mendapatkan laknat adalah menampakkan perhiasan, emas, dan mutiara yang berada di bawah niqab (tutup kepala) nya, memakai berbagai wangi-wangi seperti al-misk. Apabila memanjangkan lengannya (hingga melampaui batas). Semuanya itu termasuk jenis tabarruj yang dimurkai oleh Allah, dan pelakunya dimurkai didunia maupun diakhirat. Lantaran perbuatan ini banyak dilakukan oleh kaum perempuan, maka Rasulullah bersabda dalam hadisnya:

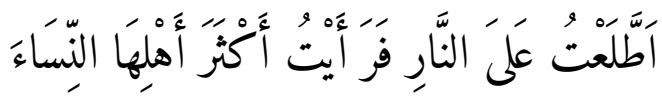

Artinya: "Saya melongok ke neraka dan saya lihat kebanyakan penghuninya adalah kaum wanita" (HR Bukhari dan Muslim). ${ }^{10}$

Dalam Al-Qur'an sangat jelas bahwasanya konsep aurat sebenarnya tidak hanya diperuntukan bagi kaum perempuan tetapi hukum ini berlaku kepada kaum laki-laki juga terdapat batasan-batasan aurat yang harus diperhatikan. Konsep aurat beserta ketentuanketentuannya ditunjukkan kepada semua orang mukalaf dan orang yang sudah baligh. Namun terkadang kita seolah-olah samar akan dampak yang ditimbulkan karena terbuka aurat kepada seorang perempuan. Sehingga seolah-olah hanya aurat seorang perempuanlah yang mempunyai banyak efek negatif kepada kaum laki-laki.

Al-Qur'an mempersilahkan perempuan berjalan dihadapan laki-laki, tetapi diingatkannya agar cara berjalannya jangan sampai mengundang perhatian. Al-Qur'an juga tidak melarang perempuan berbicara kepada laki-laki dengan syarat jangan sampai sikap dan isi pembicaraanya mengundang rangsangan dan godaan. Sehingga akan terjadi hal yang membawa kita terjerumus kedalam zina. Karena Allah SWT telah menciptakan segala sesuatu dengan kekuasaan-Nya. Laki-laki diciptakan oleh Allah memiliki sesuatu yang has yang tidak dimiliki oleh perempuan, demikian pula dengan perempuan mereka diciptakan oleh Allah memiliki sesuatu yang has dan keunikan yang tidak dimiliki pada diri laki-laki.

Para ulama tidak berbeda pendapat tentang masalah ayat diatas. Yang berbeda hanya pada masalah apakah wajah dan telapak tangan wajib ditutup. Sebagian mengatakan wajib untuk menutupinya, dan sebagian menyatakan wajah boleh dibuka. Rasulullah SAW menegaskan kepada kita semua bahwasanya seorang muslim dan muslimah hendaklah menutup auratnya dengan syariat islam.

\section{Asbabun Nuzul Surat An-Nur Ayat 31}

Adapun asbabun nuzul dari surat An-Nur ayat 31 diatas adalah, Ibnu Abu Hatim telah meriwayatkan dari Jabir Ibnu Abdullah ia berkata: bahwa Asma melihat seorang perempuan datang di kebun kurma miliknya, tanpa memakai kain sarung sehingga kelihatan perhiasan kaki mereka dan dada terlihat menyumbul serta ujung-ujung rambutpun kelihatan. Gelang kaki mereka diberi keroncongan, lalu perempuan itu berjalan di depan seorang laki-laki dengan memukul-mukulkan kakinya ketanah sehingga terdengarlah suara nyaring beradunya gelang kaki dengan keroncongannya.

\section{Penafsiran Surat Al-Ahzab Ayat 59}




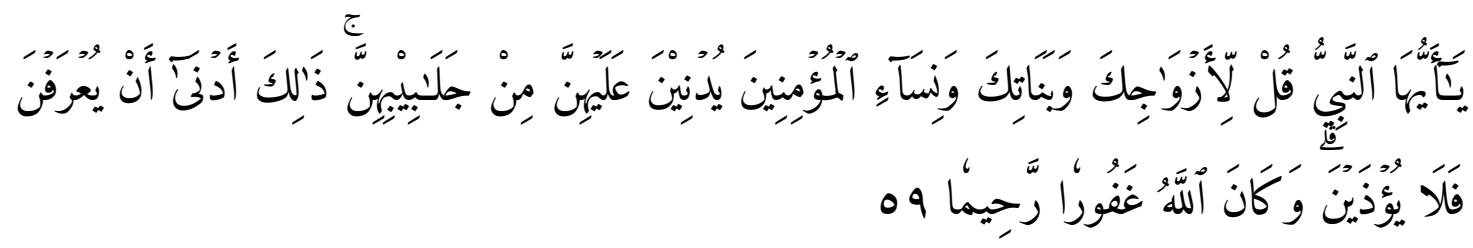

Artinya; "Hai Nabi, katakanlah kepada isteri-isterimu, anak-anak perempuanmu dan isteri-isteri orang mukmin. Hendaklah mereka mengulurkan jilbabnya ke seluruh tubuh mereka. Yang demikian itu supaya mereka lebih mudah untuk dikenal, karena itu mereka tidak di ganggu. dan Allah adalah Maha Pengampun lagi Maha Penyayang”. (Q.S. 33. Al-Ahzab: 59)

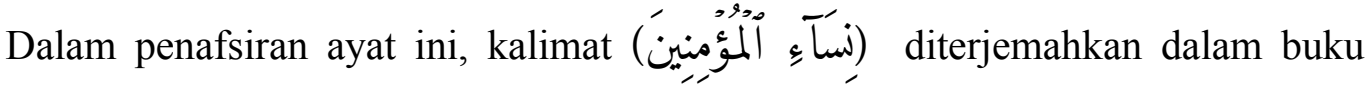
Tafsir Jalalain yaitu, istri-istri orang mukmin. Menurut buku Tafsir Jalalain ayat ini menjelaskan tentang perbedaan perempan merdeka dan perempuan hamba sahaya. Karna sebelum turunnya ayat ini, cara berpakaian perempuan merdeka atau budak yang baik-baik atau yang kurang sopan, hampir dapat dikatakan sama. Karena itu laki-laki usil sering kali mengganggu perempuan-perempuan, khususnya yang mereka ketahui atau juga sebagai hamba sahaya. Untuk menghindarkan gangguan tersebut, serta menampakkan perempuan muslimah, maka turunlah ayat ini.

Kalimat jalabib di artikan dalam Tafsir Jalalain sebagai bentuk jamak dari lafadz jilbab yaitu, kain yang di pakai oleh seorang perempuan untuk menutupi seluruh tubuhnya. Maksudnya hendaklah mereka mengulurkan sebagian dari kain jilbabnya itu untuk menutupi muka mereka, ketika mereka hendak keluar rumah. Kecuali hanya bagian yang cukup untuk satu mata, supanya mereka lebih mudah atau lebih gampang dikenal. Bahwasanya mereka adalah perempuan-perempuan merdeka sehingga mereka tidak ada yang berani mengganggunya. Berbeda halnya dengan perempuan hamba sahaya, mereka tidak di perintahkan untuk menutupi mukanya, sehingga orang-orang munafik selalu mengganggu mereka.

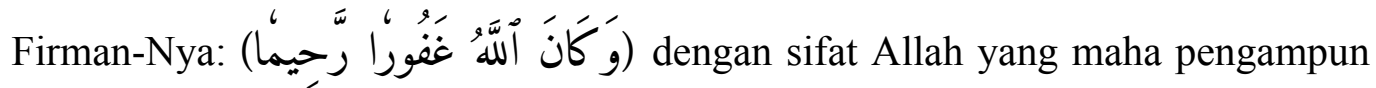
lagi maha penyanyang Allah mengampuni perempuan-perempuan mukmin yang merdeka, yaitu tidak mnutupi wajah mereka. Sebelum turunnya ayat ini. dapat juga dikatakan bahwa kalimat ini sebagai isyarat bahwa mengampuni perempuan-perempuan masa kini yang pernah terbuka auratnya dan tidak sepenuhnya melaksanakan tuntunan Allah dan nabi selama mereka sadar akan kesalahannya. Dan Allah akan lebih menyanyangi umatnya yang benar-benar ingin bertaubat dengan berusaha sekuat tenanga untuk menyesuaikan diri dengan petunjuk-petunjuk-Nya.

Menurut Tafsir Munir karangan Al-Imam Abul Fida Isma'il Ibnu Kasir AdDimasyqi dalam ayat menjelaskan, Allah SWT meminta Rasul-Nya agar memerintahkan kepada 
kaum perempuan mukminah terutama istri- isrti beliau dan anak-anak perempuan beliau, agar apabila pergi keluar rumah supaya menutup dan menjulurkan jilbab mereka supaya penampilan mereka berbeda dengan para hamba sahaya perempuan dan bisa dikenal.

Jilbab adalah rida' (pakaian yang digunakan untuk menutupi tubuh bagian atas) yaitu yang dikenakan diatas kerudung. Terdapat sejumlah riwayat yang menjelaskan tentang bentuk dan bagaimana caranya. Ibnu Abbas mengatakan, bahwasanya Allah SWT memerintahkan kepada kaum perempuan mukminin ketika mereka pergi keluar dari rumah mereka untuk suatu keperluan, agar menutupi wajah mereka dari atas kepala dengan jilbab, dan hanya satu mata saja yang ditampakkan.

Abburrazzaq dan Ibnu Abi Hatim meriwayatkan dari Ummu Salamah, dia

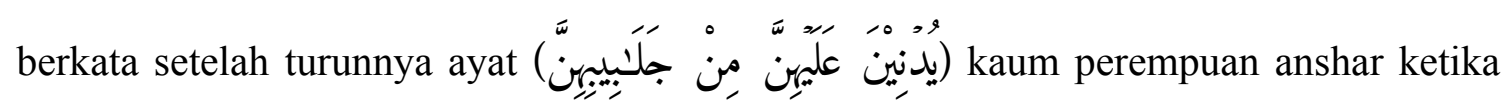
pergi keluar rumah terlihat begitu tenang, seakan-akan diatas kepalanya terdapat burung gagak, dan mereka menggunakan penutup berwarna hitam. Yang dimaksud dengan ayat ini yang diturunkan ketika syari'at telah mapan adalah supaya penutupan aurat yang diperintahkan, agar tidak berenti pada hal yang diwajibkan saja akan tetapi hendaklah lebih dari itu. Hal ini merupakan adab yang baik yang bisa menjauhkan seorang perempuan dari prasangka, fitnah, dan kecurigaan yang bukan-bukan, serta lebih menjamin keselamatannya dari gangguan orang-orang fasik.

Pakaian syar'i adalah pakaian yang bisa menutupi seluruh tubuh dan tidak menerawang. Jika seorang perempuan berada didalam rumah dan didepan suami sendiri, maka diperbolehkan menggunakan pakaian apa saja yang diinginkannya.

Al-Imam Abul Fida Isma'il Ibnu Kasir Ad-Dimasyqi dalam menafsirkan ayat

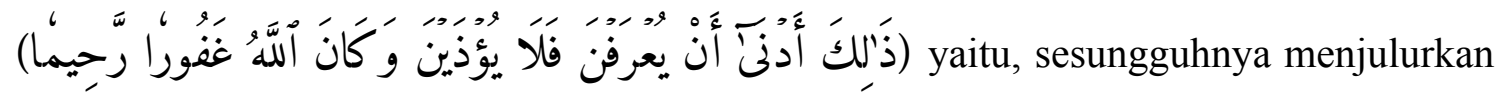
jilbab atau menutupi seluruh tubuh seperti itu membuat mereka lebih mudah dikenal bahwa mereka adalah perempuan merdeka. Bukan hamba sahaya perempuan dan bukan pula perempuan nakal. Dengan begitu mereka tidak akan di ganggu dari orang-orang fasik, nakal, dan berhidung belang.

Allah SWT maha pengampun terhadap apa yang pernah mereka lakukan berupa perbuatan mengabaikan perintah menutup aurat dengan sempurna. Maha pengampun bagi orang yang nematuhi perintah-Nya ketika dia kurang sempurna, dalam menutupi aurat secara salah dan tidak sengaja. Allah SWT juga meluaskan rahmat-Nya kepada hamba-hamba-Nya, karena Allah senantiasa memperhatikan kemashlahatankemashlahatan mereka, serta memberi tuntunan dan bimbingan adab yang baik.

Adapun pendapat Jumhur Ulama untuk hamba sahaya perempuan, syara' mereka diberi kelonggaran dengan tidak mentaklif mereka untuk menutupi tubuh secara keseluruhan, agar mereka tidak terlalu berat mengalami kerepotan ketika harus menutup wajahnya. Serta mempermudah mereka dalam melaksanakan tugasnya dalam memberikan pelayanan kepada majikannya.

Dalam buku Tafsir Munir ayat ini dijadikan dasar dalil tentang keharusan seoarang perempuan untuk menutup wajahnya. Karena para ulama dan mufassir semisal Ibnu Jauzi, Ath-Thabari, Ibnu Kasir, Abu Hayyan, Abu As-Saud dan Ar-Razi 
menafsirkan perintah mengulurkan jilbabnya. Isi ayat ini sudah jelas pengertiannya untuk menutupi wajah, seluruh tubuh dan rambut, dari laki-laki asing atau ketika keluar rumah untuk suatu keperkuan. ${ }^{11}$


istri orang mukmin. Quraish Shihab lebih cenderung menerjemahkannya dengan perempuan-perempuan orang mukmin. Sehingga ayat ini mencakup juga gadis-gadis semua orang mukmin, bahkan keluarga mereka semuanya. ${ }^{12}$

Ulama-ulama terdahulu menyatakan bahwa ayat diatas merupakan tuntunan kepada istri-istri Nabi serta kaum muslimah agar mereka memakai jilbab. Hampir semua ulama memahami ayat diatas berlaku bukan saja pada zaman Nabi SAW. Tetapi juga sepanjang masa hingga kini dan masa yang akan datang. Namun demikian, sementara ulama kontemporer memahaminya hanya berlaku pada zaman Nabi SAW. Dimana ketika itu ada perbudakan dan diperlukan adanya pembeda antara mereka dan perempuan-perempuan merdeka, serta menghindarkan gangguan lelaki usil. ${ }^{13}$

Sedangkan pada lafadz jalabib menurut Quraish Shihab sebagai bentuk jamak dari kata jilbab yang mengandung arti baju kurung yang longgar yang dilengkapi dengan kerudung penutup kepala. Selain itu Quraish Shihab dalam menafsirkan kalimat "yang demikian itu menjadikan mereka lebih mudah dikenal" yakni sebagai perempuanperempuan terhormat atau perempuan-perempuan muslimah, atau sebagai perempuanperempuan merdeka sehingga demikian mereka tidak akan diganggu. ${ }^{14}$ Didalam bukunya yang berjudul jilbab pakaian muslimah Quraish Shihab menyatakan bahwa: "yang penting dari pakaian perempuan adalah penampilan mereka dalam bentuk terhormat sehingga tidak mengundang gangguan yang usil." 15

Menurut Quraish Shihab ayat diatas tidak memerintahkan perempuan muslimah memakai jilbab karena agaknya ketika itu sebagian mereka telah memakainya, hanya saja cara memakainya belum mendukung apa yang dikehendaki ayat ini. Kesan ini di peroleh dari redaksi ayat diatas yang menyatakan jilbab mereka dan yang diperintahkan adalah "Hendaklah mereka mengulurkan jilbabnya,"

Menurut Thaba'thaba'i memahami kata jilbab diartikan sebagai pakaian yang menutupi seluruh badan atau kerudung yang menutupi kepala dan wajah perempuan. Sedangkan Ibnu Asyur memahami kata jilbab diarti sebagai pakaian yang lebih kecil dari jubah tetapi lebih besar dari kerudung atau penutup wajah. Menurut Ibnu Asyur jilbab itu banyak modelnya sesuai perbedaan atau selera perempuan, dan yang diarahkan oleh adat kebiasaan. ${ }^{16}$

11 Wahbah Az-Zuhaili, Tafsir Al-Munir : Aqidah, Syari'ah, Manhaj, jilid 11, Op-Cit, hal. 426-427

12 M. Quraish Shihab,Tafsir Al-Misbah: Pesan Kesan dan Keserasian Al-Qur'an, (Jakarta: Lentara Hati, 2011), Hal. 533 hal. 89

13 M. Quraish Shihab, Jilbab: Pakaian Wanita Muslimah, (Tanggerang Selatan: Lentera Hati, 2014),

14 M. Quraish Shihab, Tafsir Al-Misbah, Op-Cit, hal. 533

15 M. Quraish Shihab, Jilbab: Pakaian Wanita Muslimah, op-cit, hal.167

16 M. Quraish Shihab, Tafsir Al-Misbah, Op-Cit, hal. 533 


\section{Asbabun Nuzul Surat Al-Ahzab Ayat 59}

Asbabun nuzul surat Al-Ahzab ayat 59 ialah, Imam Bukhari telah meriwayatkan sebuah hadis yang bersumber dari Siti Aisyah R.A yang telah menceritakan bahwa Siti Saudah pergi keluar untuk suatu keperluannya dan ia adalah seorang perempuan yang tubuhnya besar, sehingga ia dapat dikenali oleh orang lain. Kemudian umar melihatnya, lalu ia berkata: "Hai Saudah ingatlah demi Allah kamu tidaklah samar bagi kami sekalipun kamu sudah memakai hijab, maka dalam keadaan bagaimana pun kamu pasti aku akan mengenalimu”. Lalu Siti Saudah pulang dan bertemu dengan Rasulullah SAW, kemudian ia menceritakan kepada Rasulullah bahwasanya ia telah keluar untuk suatu keperluan. Lalu di tengah jalan bertemu dengan Umar dan Umar mengatakan demikian kepadaku. Kemudian Rasulullah menjawab "Sesungguhnya Allah telah memberi izin kepada kalian semua untuk keluar bila bila memang kalian mempunyai keperluan”.

Ibnu Sa'ad di dalam kitab tabaqat-nya telah meriwayatkan sebuah hadis melalui Abu Malik yang telah menceritakan bahwa istri-istri Nabi SAW. Selalu keluar malam hari untuk suatu keperluan mereka, sehingga segolongan orang-orang munafik menggodanya dan membuat mereka sakit hati. Lalu mereka mengadukan hal tersebut kepada Nabi SAW. Kemudian orang-orang munafik itu di tanya, dan mereka menjawab: "Sesungguhnya kami melakukan hal itu hanya dengan memakai isyarat yakni bukan dengan perkataan". Maka Allah SWT menurunkan firman-Nya.

Artinya; Hai Nabi, katakanlah kepada isteri-isterimu, anak-anak perempuanmu dan isteri-isteri orang mukmin: "Hendaklah mereka mengulurkan jilbabnya ke seluruh tubuh mereka". Yang demikian itu supaya mereka lebih mudah untuk dikenal, karena itu mereka tidak di ganggu. (Q.S. Al-Ahjab [33]: 59) ${ }^{17}$

\section{Konsep Pendidikan Akhlak Dalam Surat An-Nur Ayat 31 dan Surat Al-Ahzab Ayat 59}

Pendidikan adalah suatu proses perubahan sikap, tingkah laku seseorang dalam usaha pendewasaan manusia terhadap berbagai masalah dan problem-problem yang ada, karena dengan pendidikan kita akan lebih terarah dan disiplin. Sehingga kita hidup didunia ini memiliki akhlak mulia. Sebagaimana sabda Nabi SAW:

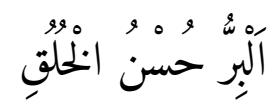

Artinya: “ Kebaikan itu berakhlak mulia”. (HR.At-Tirmidzi) $)^{18}$

Ilmu tanpa akhlak bagaikan api tanpa kayu bakar, dan akhlak tanpa ilmu bagaikan jiwa tanpa jasad. Inilah yang menyebabkan manusia harus berakhlak dan berilmu, jika salah satu darinya tidak ada maka akan tampak sekali ketidak seimbangan hidup seseorang didunia ini. Oleh karena itu berakhlak itu sangat penting untuk menjaga kestabilan dalam hidup bermasyarakat, berbangsa, dan bernegara sekalipun. Jika akhlak tidak ada pada diri manusia maka bagaimana caranya bermuamalat, berinteraksi dengan sesama manusia dan cara melahirkan kasih sayang, hubungan silaturahmi dan menjalin hablum minannas (interaksi antar sesama manusia).

17 Jalaluddin Al-Mahali, Jalaluddin -Suyuti, Tafsir Jalalain, Op-Cit, hal. 541-542

18 Samsul, Ilmu Akhlak, Op-Cit. hal. 17 
Tujuan yang mendasar dari akhlak Islam adalah tidak lain untuk mencapai kebahagiaan. Kebahagiaan tersebut adalah kebahagiaan yang dapat melindungi dirinya sendiri dan umat, inilah yang disebut dengan kebahagiaan sejati bukan kebahagiaan yang bersifat khayalan dan angan-angan belaka. Adapun dasarnya, tujuan pokok akhlak dalam Islam adalah agar setiap muslim berbudi pekerti dan bertingkah laku yang baik dan mulia sesuai dengan ajaran Islam.

Adapun kunci utama untuk mencapai kebahagiaan yang kekal dan abadi yaitu mendapatkan ridha Allah. Karena tanpa ridha Allah kebahagiaan yang sejati dan abadi tidak akan diraih. Dan untuk mendapatkan ridha Allah yaitu dengan cara bertakwa kepada Allah, karena sesungguhnya esensi dari akhlak Islam adalah takwa.

Dalam surat An-Nur ayat 31 menjelaskan tentang akhlak perempuan dalam pandangan yang membangkitkan syahwat. Maka laki-laki serta perempuan dianjurkan untuk menahan pandangannya. Sebab pandangan yang tercemari oleh syahwat pada lawan jenis merupakan langkah untuk melakukan dosa dan kerusakan karena itu akar dosa ini harus disingkirkan. Dan telah di jelaskan pula dengan transparan bahwa memandang aurat orang lain (lelaki, perempuan, muhrim dan non muhrim) adalah dilarang. Topik lain yang perlu diperhatikan pada ayat ini adalah kewajiban menutup leher, dada dan seputar anggota badan wanita yang kebanyakan di jadikan pusat perhatian oleh lawan jenis.

Demikian juga dalam ayat ini menunjukkan bahwa adanya larangan berhias dan berdandan untuk yang non muhrim, kecuali apa yang telah nampak darinya, dan sambungan dari ayat sebelumnya, dengan jelas telah melarang secara mutlak untuk tidak menunjukkan dan mempertontonkan keindahan diri kepada yang non muhrim, dan

kalimat itu adalah

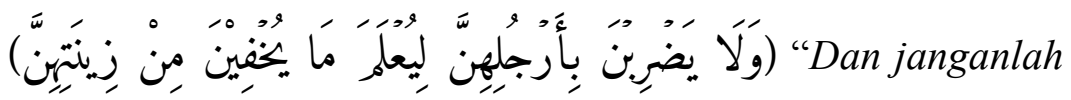

mereka memukulkan kakinya agar diketahui perhiasan yang mereka sembunyikan" seperti khalkhal yang di pakai oleh perempuan-perempuan arab, bahkan badan sampai pergelangan tangan dan juga kaki harus ditutup. Disamping itu ayat ini telah menjelaskan tentang falsafah hijab dan kehormatan menahan pandangan yang di antaranya adalah menghindari terjadinya kesalahan dan kerusakan.

Menjaga kehormatan dan harga diri manusia khususnya kehormatan perempuan adalah suatu asas yang telah diterima dalam agama Islam serta dalam seluruh aturanaturan dan hukum-hukumnya. Dan masalah hijab adalah merupakan salah satu dari perkara tersebut. Al-Quran Karim telah menjelaskan berbagai topik hijab dalam berbagai bentuk, gambaran, dan ibarat yang berbeda-beda. Oleh karena itu, hijab dipandang sebagai suatu kewajiban dalam agama Islam dan apabila seseorang mengingkarinya maka dia telah mengingkari satu hukum yang telah diwajibkan dalam agama dan mengingkari kewajiban agama berarti terjerumus di dalam kekafiran.

Perlu diketahui bahwa tidak semua aturan-aturan Islam itu dibahas dalam AlQuran, karena Al-Quran adalah sebuah aturan pokok yang hanya memberikan pembahasan secara global dan masalah-masalah detailnya diserahkan kepada mufassir Al-Quran, yakni Rasulullah SAW dan para awliya di mana mereka mengambil sumber dari wahyu, disisi lain juga kebanyakan hukum-hukum tidak dibahas secara detail dalam 
Al-Quran, akan tetapi dibahas dengan terang dan jelas di dalam fiqih Islam. Adapun masalah hijab terdapat beberapa ayat yang dijelaskan dengan detail di dalam Al-Quran, oleh karena itu sebagian orang yang tidak memiliki informasi tentang hijab, mereka menciptakan suatu keraguan dan kesangsian di dalam pikiran perempuan sehingga menanyakan "Memangnya hijab juga terdapat dalam Al-Quran"? pertanyaan ini sampai kapanpun tidak akan pernah tepat, sebab Al-Quran dengan jelas telah membahas topik tentang hijab dan setiap orang yang mengakui dirinya muslim, maka dia tidak boleh mengingkari masalah hijab dalam islam.

Dalam penafsiran ayat diatas para ulama tidak banyak perbedaan pendapat tentang masalah hijab. Yang menjadi perbedaan pendapat adalah tentang apakah wajah dan telapak tangan wajib di tutup atau tidak? Sebagian mengatakan wajib dan sebagian mengatakan wajah boleh di buka. Karena sebagian ulama mengatakan aurat perempuan adalah seluruh tubuh kecuali wajah dan telapak tangan. Sedangkan sebagian ulama yang mewajibkan wajah harus ditutup karena seluruh tubuh perempuan adalah aurat, begitupun dengan suara perempuan adalah aurat.

Sedangkan penafsiran surat Al-Ahzab ayat 59 menjelaskan tentang jilbab. Didalam menafsirkan ayat ini, para ulama banyak berbeda pendapat terutama dalam Tafsir Jalalain dan Tafsir Al-Misbah. kedua Tafsir ini banyak perbedaan penafsiran.

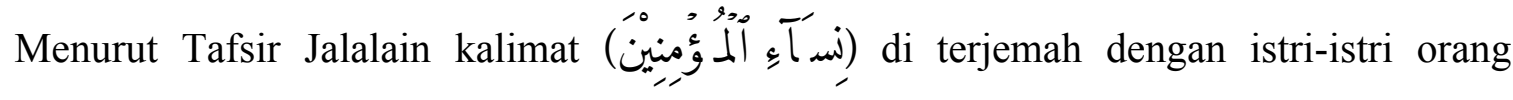
mukmin, begitupun dengan tim departemen agama mengartikannya sebagai istri-isrti orang mukmin. Sedangkan Tafsir Al-Misbah karangan Quraish Shihab lebih cenderung kepada perempuan-perempuan orang-orang muslim. Sehingga ayat ini mencakup gadisgadis semua orang mukmin. Bahkan keluarga mereka semuanya.

Perbedaan penafsiran juga pada lafadz jilbabun yang artinya jilbab. Menurut Tafsir Jalalain perempaun wajib memakai jilbab karna sudah jelas seluruh tubuh perempuan adalah aurat. Bahkan para ulama pun sepakat aurat perempuan adalah seluruh tubuh kecuali wajah dan kedua telapak tangan. Tetapi berbeda dengan penafsiran Quraish Shihab, bahwasanya "ayat diatas tidak memerintahkan perempuan muslimah memakai jilbab karena kesan yang diperintahkan adalah "Hendaklah mereka mengulurkan" ini berarti mereka sudah memakai jilbab akan tetapi mereka belum mengulurkannya. Dan perintahnya adalah untuk mengulurkan jilbabnya, karena cara memakainya belum mendukung apa yang dikehendaki ayat ini.

Kehidupan dipenuhi berbagai persoalan dan kesulitan yang tidak kita pikirkan dan memandang siapa pun. Oleh karena itu, seorang perempuan harus memiliki akhlak yang mulia. Karena perempuan sangat berperan penting dalam kehidupan ini. Sebagaimana pepatah bijak mengatakan:"Perempuan adalah tiang suatu negara, apabila perempuannya baik maka negara akan baik dan apabila perempuannya rusak maka negara pun akan rusak".

Hadis ini memberikan penjelasan kepada kita bahwa perempuan adalah yang berpengaruh dan berperan penting dalam generasi selanjutnya. Dimana seorang perempuan akan melakukan perannya sebagai anak, sebagai istri, sebagai ibu dan sebagai anggota masyarakat. Maka pendidikan perempuan itu sangat penting dalam 
memperjuangkan nilai-nilai ke-Islaman, ke-Indonesiaan, keperempuanan dan anak. Maka ajarilah pendidikan akhlak khususnya bagi perempuan dari sejak dini untuk mengenal ajaran-ajaran Islam dalam kehidupan sehari-hari seperti: Pengetahuan Agama, pengetahuan moral, dan pengetahuan etika dan tradisi. Semua itu untuk menjaga keyakinan terhadap Allah SWT, menguatkan bangunan moral, ketakwaan serta kesucian pada diri anak dan etika kehidupan pergaulan. ${ }^{19}$

Selain itu, memberikan nilai-nilai yang dapat diambil dari metode Nabi Muhammas SAW. Dalam mendidik anak usia dini adalah sebagai berikut:

1. Meluangkan waktu untuk bermain dengan anak-anak.

2. Memperaktikan amal untuk bisa berbuat bersih secara iman dan berprilaku nyata.

3. Shalat beliau dirumah menanamkan pemahaman teladan dalam urusan ibadah.

4. Kalimat yang diucapkan oleh beliau."Wahai Abu Umair, apa yang dikerjakan Nughair?" memilki beberapa faedah. Diantaranya, kata-kata akhirnya cocok dengan jiwa, mudah dihafal, dan mudah di ucapakan.

5. Menyesuaikan dengan intelek anak bisa membuahkan rasa optimis pada diri anak.

6. Memakai cara dengan panggilan. Teori ini dapat memberikan kesan kepada keluarga bahwa anaknya sudah dewasa. ${ }^{20}$

Metode diatas dapat digunakan untuk mendidik akhlak anak khusunya dalam berpakaian sesuai ajaran Islam yang terkandung dalam surat An-Nur Ayat 31 dan Surat Al-Ahzab 59. Dengan memberikan waktu kepada anak untuk bersama dan mencotontohkan keteladanan yang baik. Maka anak akan tumbuh menjadi perempuan yang sholehah dan taat menjalani perintah-Nya dan menjauhi larangan-Nya.

\section{SIMPULAN}

Kesimpulan penelitian ini adalah sebagai berikut :

1. Konsep pendidikan akhlak dalam Al-Qur'an yaitu, suatu usaha yang dilakukan secara sadar guna memberikan pendidikan jasmani dan rohani berdasarkan ajaran Islam yang berupa penanaman akhlak mulia yang merupakan cermin kepribadian seseorang. Karena dalam pendidikan seseorang akan menjadi lebih baik dan yang tidak tahu akan menjadi tahu, sehingga menghasilkan perubahan yang direalisasikan dalam kehidupan sehari-hari. Akhlak yang mulia akan mampu mengantarkan seseorang kepada martabat yang tinggi. Perbuatan mulia yang keluar dari kekuatan jiwa tanpa keterpaksaan adalah akhlak yang baik.

2. Dalam surat An-Nur ayat 31 seorang perempuan muslimah harus menutup auratnya, sedangkan aurat perempuan adalah seluruh tubuh selain yang dikecualikan. Dan menjaga martabat seorang perempuan, dengan tidak memperlihatkan auratnya kepada laki-laki lain selain mahramnya. Jangan memakai pakaian yang ketat atau pakaian yang menerawang sehingga memunculkan fitnah. Gunakan pakain yang longgar, tebal, tidak ketat dan tidak tipis, hal ini yang di perintahkan oleh Allah untuk digunakan seorang perempuan. Dan dalam surat Al-Ahzab ayat 59 yaitu Ada

19 Ija Suntana, Etika Pendidikan Anak, (Bandung: CV Pustaka Setia, 2015), hal. 59

20 Sitiatava, Rizema Putra, Metode Pengajaran Rasulullah SAW, (Yogyakarta: DIVA Press, 2016), Hal. 199-200 
beberapa hal yang mesti diperhatikan dan diterapkan pada diri perempuan, seperti anjuran memakai jilbab yang harus menutupi dada dan anggota tubuhnya, untuk menghindari fitnah. Sesungguhnya keyakinan kepada Allah SWT dan ketaatan untuk mematuhi perintah-Nya serta menjauhi larangan-Nya dan selalu istiqomah dalam menjalankan perintah-Nya untuk mencapai kebahagiaan dunia dan akhirat.

\section{DAFTAR PUSTAKA}

Al-Bani, Nasrudin Muhammad Syaikh, Jilbab Wanita Muslimah Menurut Quran dan Sunah, Solo: At-Tibyan, 2011

Al-Mahalli Jalaluddin, Jalaluddin As-Suyuti, Tafsir Jalalain, Bandung: Sinar Baru Algensindo, 2013

Az-Zuhaili, Wahbah, Tafsir Al-Munir: Aqidah, Syari'ah, Manhaj, Depok: Gema Insani, 2016

Depag RI, Al-Qur'an dan Terjemahan, Semarang: CV Asy-Syifa, 1998

Ibnu Kasir Ad-Dimasyqi, Al-Imam Abul Fida Isma'il, Tafsir Ibnu Kasir, Juz 18, Bandung: Sinar Baru Algensindo, 2007

Munir, Samsul, Ilmu Akhlak, Jakarta: Amzah, 2016

Muthahhari, Murtadha, Teologi Falsafah Hijab, Yogyakarta: Rausyanfikr Institute, 2015

Putra Rizema, Sitiatava, Metode Pengajaran Rasulullah SAW, Yogyakarta: Diva Press, 2016

Shihab, M Quraish, Tafsir Al-Misbah: Pesan, Kesan, dan Keserasian Al-Qur'an, Jakarta: Lentera Hati, 2011 , Jilbab Pakaian Wanita Muslimah, Jakarta: Lentera Hati, 2014

Sugiono, Metode Penelitian Pendidikan, Bandung: Alfabeta, 2015

Suntana, Ija, Etika Pendidikan Anak, Bandung: CV Pustaka Setia, 2015 